\title{
Mulch Types Affect Fruit Quality and Composition of Two Strawberry Genotypes
}

\author{
Shiow Y. Wang ${ }^{1}$, Gene J. Galletta ${ }^{1}$, and Mary J. Camp ${ }^{2}$ \\ Beltsville Agricultural Research Center, Agricultural Research Service, U.S. \\ Department of Agriculture, Beltsville, MD 20705
}

\section{Michael J. Kasperbauer \\ Coastal Plains Soil, Water, and Plant Research Center, Agricultural Research Service, U.S. Department of Agriculture, Florence, SC 29501-1241}

Additional index words. Fragaria $\times$ ananassa, acid, sugar, fruit color, black polyethylene, red polyethylene, straw-vetch

\begin{abstract}
The influence of mulch types (black polyethylene, red polyethylene, and strawvetch in raised bed hill culture) on the chemical composition of 'Northeaster' and 'Primetime' strawberry (Fragaria $\times$ ananassa Duch.) fruit and plant parts was evaluated. Ascorbic acid (AA), malic acid, citric acid, and ellagic acid levels were higher in 'Primetime' than in 'Northeaster' fruits, while 'Northeaster' had a higher soluble solids content (SSC). Fruit grown on straw-vetch had lower SSC than did those grown on the polyethylene mulches. The AA content in the fruit of either cultivar was not affected by the mulch treatment. Fruit grown on the straw-vetch mulch had less red surface and flesh color but higher pigment intensity than fruit grown on the polyethylene mulches. Strawberry plants grown on straw-vetch mulch had the largest leaf area and the highest chlorophyll content, while plants grown on red polyethylene mulch had the smallest leaf area and lowest chlorophyll content. There were significant mulch $\times$ cultivar interactions in fruit titratable acid (TA) and AA levels, sugars, citric and ellagic acid contents, leaf area and chlorophyll levels, and soluble carbohydrate and starch contents in leaves, petioles, crowns, crownroots, and roots. TA was highest in 'Northeaster' fruit when grown on red polyethylene, whereas TA was highest in 'Primetime' fruit when grown on straw-vetch. The highest fruit citric acid levels were found in straw-vetch mulched plots of 'Northeaster', and in black polyethylene mulched plots of 'Primetime'. Ellagic acid accumulation was highest in 'Northeaster' fruit grown on black polyethylene, and in 'Primetime' fruit grown on red polyethylene or straw-vetch mulches. Fruit glucose content was highest in 'Northeaster', but lowest in 'Primetime', when grown on the straw-vetch mulch. There was a general tendency for soluble carbohydrate and starch levels in plant tissues to be lowest when the plants were grown in red polyethylene mulch and highest when grown in black polyethylene mulch. 'Primetime' contained higher total carbohydrate levels than did 'Northeaster' in all tissues tested.
\end{abstract}

High-density annual strawberry production using a raised bed hill culture system is a common practice in California (Cannell et al., 1961) and Florida (Locascio and Smart, 1968). Recently, growers in eastern and northern states have utilized this system, which provides enhanced weed control, earlier harvest, increased yield and fruit size, prevention of bed erosion and cleaner fruit (Baumann and Eaton, 1991; Baumann et al., 1995; Himelrick,

Received for publication 3 Mar. 1997. Accepted for publication 20 Oct. 1997. The authors wish to thank J.M. Enns for setting up the experiment and for strawberry field care, and W.M. Lee and Y.J. Chang for technical assistance. Use of a company or product name by the USDA does not imply approval or recommendation of the product to the exclusion of others which also may be suitable. The cost of publishing this paper was defrayed in part by the payment of paper charges. Under postal regulations, this paper therefore must be hereby marked advertisement solely to indicate this fact.

${ }^{1}$ Fruit Laboratory.

${ }^{2}$ Biometrical Consulting Service.
1982; Scheel, 1982). Many synthetic and organic mulches have been used in the raised bed culture system, but black polyethylene mulch has become the standard for annual production of eastern U.S. strawberries. Himelrick (1982) showed that plants grown on black plastic mulch produced more runners and fruit than plants grown on clear or white plastic mulches and that total fruit mass was greater with black and clear plastic mulches than with bare soil. Baumann et al. (1995) reported no yield differences between green and black plastic mulch, but plants on black mulch produced larger berries than did those on green or no plastic mulch. In a 2-year field test in Florida, strawberry plants grown over red-painted plastic produced larger berries than did plants grown over black polyethylene (Albregts and Chandler, 1993). In previous tests at Beltsville, strawberries grown on red-painted black plastic on raised beds had slightly higher yields and ripened slightly later than those grown on black plastic-covered beds (Galletta et al., 1996). Red mulch also enhanced early har- vests, fruit size, and yields in tomatoes (Decoteau et al., 1989). Organic mulches such as straw-vetch have provided environmental benefits. These include: increased nitrogen; recycling of nutrients; reduced soil erosion, weed emergence, and water loss; addition of organic matter to the soil; lower soil temperature during the hot summer months; and action as a slow-release fertilizer (Abdul-Baki and Teasdale, 1993). Using a killed sod mulch cover for strawberries reduced erosion and compaction, improved soil structure, and reduced water loss in comparison with nonmulched raised beds (Takeda and Glenn, 1988).

Sugars and organic acids have an important impact on sensory quality of strawberry fruit. A strawberry with very low sugar and acid content tastes flat. Ellagic acid functions as an antimutagen, anticarcinogen, and a potential inhibitor of chemically induced cancers (Maas et al., 1991a, 1992; Okuda et al., 1989). Strawberries contain high amounts of ellagic acid (Maas et al., 1991b; Wang et al., 1994). Large differences in ellagic acid content have been found among species, cultivars, and tissues, and variation is also affected by environmental factors (Wang et al., 1994). However, little attention has been focused on fruit quality and chemical composition of plants grown under different mulch systems. The objective of the present study was to compare the effects of several mulch types (black polyethylene, red polyethylene, and straw-vetch) in raised bed hill culture on the fruit quality and chemical composition of two new strawberry cultivars, 'Northeaster' and 'Primetime'.

\section{Materials and Methods}

Plant material and field experiments. The strawberry cultivars used were two of the newer introductions from the U.S. Dept. of Agriculture-Beltsville cooperative breeding program; the early-ripening 'Northeaster' (introduced in 1994), and the midseason 'Primetime" (introduced in 1995). The field portion of the experiment was conducted on a Matawan-Hammonton loamy sand on the North Farm of the Beltsville Agricultural Research Center in Beltsville, Md. Twelve raised beds were prepared $1.8 \mathrm{~m}$ from center to center, $17 \mathrm{~cm}$ high, and $17 \mathrm{~m}$ long. Six of the beds were prepared in Sept. 1994. The tops were sown with hairy vetch, which germinated and developed through the fall and provided a winter cover crop. To prevent overwinter bed erosion and deformation, the remaining six beds were formed in Apr. 1995, and a central trickle irrigation line was installed simultaneously under black polyethylene mulch (1.1 mil) stretched over the beds. At the same time, the vetch cover on the initial six beds was mowed, and a central trickle line was stretched down these beds. The vetch and the black poly-covered beds were placed side by side, alternating every two rows across the field. Each bed was planted with one row each of 'Primetime' and 'Northeaster' at $30 \times 30 \mathrm{~cm}$ between and within rows on 3 May 1995 . The cultivar planting position on each bed was 
randomly chosen. Following planting, chopped rye straw for weed and moisture control was placed between all beds, and also over the vetch sod rows, to provide additional biomass. Water and fertilizer (ammonium nitrate, 78.45 $\mathrm{kg} \cdot \mathrm{ha}^{-1}$ ) was applied through the trickle system during the first growing season. An additional $16.8 \mathrm{~kg} \cdot \mathrm{ha}^{-1}$ of $20 \mathrm{~N}-20 \mathrm{P}-20 \mathrm{~K}$ was applied the following spring in three applications of $5.61 \mathrm{~kg}$ each. Runners were removed from the plants during the first season (only the mother plants were retained). No fungicides, insecticides, or herbicides were used in this planting and spot weeding was done by hand. Additional rye straw winter mulch was applied over the beds in Dec. 1995 to just cover the plants.

After the winter straw mulch was removed in Apr. 1996, 15 plots (five plots per mulch with 10 plants of each cultivar per plot) were selected from each of the three mulch treatments: mowed vetch-straw mulch; black polyethylene mulch; and black polyethylene mulch overlaid with a 1-mil-thick layer of red polyethylene mulch. The red mulch was applied over the black because the red mulch alone did not prevent weed germination by itself. The red mulch was applied in the spring of the fruiting season to test whether a short duration of treatment would give the enhanced yield, and size and early ripening effects reported for other crops. In each plot, the first eight plants of each cultivar were harvested for yield, size, and time of ripening (data not reported here). The last two plants of each cultivar per plot were used for the chemical and physical analyses of the fruit and plant, as outlined below. Ten firm-ripe fruit with well-developed red color and free from defects or decay were harvested from every plot for each cultivar three times at 3-d intervals during the fruiting season for color evaluation and chemical analyses at about $0900 \mathrm{HR}$. Data for the individual harvests were pooled. Weather during the ripening season ranged from overcast to sunny, with the average maximum temperature 15.5 ${ }^{\circ} \mathrm{C}$, and the minimum temperature $8.5^{\circ} \mathrm{C}$.

Color assessment. Ten berries were sampled per plot every harvest time. Two readings were taken on opposite sides of each berry for surface and flesh colors (Sacks and Shaw, 1994) using a handheld reflectance colorimeter (model CR-10, Minolta; Spectrum Technologies, Plainfield, Ill.). Color was recorded using the CIE- $L^{*}, a^{*}, b^{*}$ uniform color space, in which the $L^{*}$ scale ranges from no reflection $\left(\mathrm{L}^{*}=0\right.$, black) to perfect diffuse reflection $\left(L^{*}=100\right.$, white), the $a^{*}$ scale ranges from negative values for green to positive values for red, and the $b^{*}$ scale ranges from negative values for blue to positive values for yellow. Numerical values of $a^{*}$ and $b^{*}$ were converted into hue angle $\left(H=\tan ^{-1} b^{*} /\right.$ $\left.\mathrm{a}^{*}\right)$ and chroma [chroma $=\left(\mathrm{a}^{* 2}+\mathrm{b}^{* 2}\right)^{1 / 2}$ ] (Francis, 1980). The value of $\mathrm{H}$ is the angle in a color wheel of $360^{\circ}$, with $0,90,180$, and 270 representing hues red-purple, yellow, bluishgreen, and blue, respectively, while chroma is the intensity or purity of the hue.

Chlorophyll analysis and leaf area measurement. Ten healthy, mature, fully expanded leaves per genotype per plant per plot were used for chlorophyll analysis and leaf area measurement. The chlorophyll content was measured nondestructively with a SPAD-502 meter (Minolta; Spectrum Technologies). Higher chlorophyll meter units indicate higher chlorophyll content. Data obtained using this technique are highly correlated with extractable chlorophyll levels (Marquard and Tipton, 1987). The correlation coefficient between the SPAD-502 unit and extractable chlorophyll level in strawberry leaves is 0.964 . Strawberry leaf area was measured with a portable area meter(LI-3000; LI-COR, Lincoln, Nebr.). The leaves, petioles, crowns, crown-roots, and roots from each plant were then cut into small pieces, composted, and frozen.

Soluble solids (SSC) and titratable acids (TA). Following color measurement, the fruits were cut into small slices, composted, and subsampled. Portions for carbohydrate, organic acid, ascorbic acid, and ellagic acid analysis were frozen. A portion was pressed through cheesecloth to express the juice used for SSC and TA determinations. The SSC of the fruit was determined on a digital refractometer Palette 100 PR-100 (ATAGO-Spectrum Technologies, Plainfield, Ill.) standardized with distilled water. TA was determined by diluting each $5-\mathrm{mL}$ aliquot of strawberry juice to $100 \mathrm{~mL}$ with distilled water and adjusting the $\mathrm{pH}$ to 8.2 using $0.1 \mathrm{~N} \mathrm{NaOH}$. Acidity was expressed as milligrams of citric acid per $100 \mathrm{~mL}$ of juice.

Carbohydrate determination. Tissues (20 $\mathrm{g}$ of composite fresh fruit tissues from 10 berries and $5 \mathrm{~g}$ of tissue for leaves, petioles, crown, crown-root, and roots) were extracted with $40 \mathrm{~mL}$ of $80 \%$ ethanol, then centrifuged at $5000 \times g_{\mathrm{n}}$ for $5 \mathrm{~min}$. The residue was reextracted and washed twice by centrifugation and resuspended in $80 \%$ ethanol $(20 \mathrm{~mL}$ each time). The supernatants were combined (the final total volume for each sample was $100 \mathrm{~mL}$ ethanol) and an aliquot of the extract was concentrated to dryness in vacuo in $5-\mathrm{mL}$ derivatizing vials and used for sugar analysis. The residue from the ethanol extraction was extracted with acetone, n-hexane, and $80 \%$

Table 1. Fruit surface and flesh color of 'Northeaster' and 'Primetime' strawberries grown in different mulch types.

\begin{tabular}{|c|c|c|c|c|c|c|c|}
\hline & & \multicolumn{3}{|c|}{ Fruit surface color } & \multicolumn{3}{|c|}{ Fruit flesh color } \\
\hline & & $\mathrm{L}^{2}$ & Hue $^{y}$ & Chroma $^{\mathrm{x}}$ & $\mathrm{L}$ & Hue & Chroma \\
\hline \multicolumn{8}{|c|}{ Treatment (GC) } \\
\hline \multicolumn{2}{|c|}{ Black polyethylene } & 26.75 & 17.24 & 31.84 & 50.96 & 26.31 & 31.74 \\
\hline \multicolumn{2}{|c|}{ Red polyethylene } & 26.58 & 17.02 & 31.65 & 51.20 & 27.22 & 32.19 \\
\hline \multicolumn{2}{|c|}{ Straw-vetch } & 27.05 & 18.34 & 32.65 & 49.94 & 28.78 & 33.12 \\
\hline $\mathrm{LSD}_{0.05}$ & & NS & 0.64 & 0.47 & 0.87 & 0.55 & 0.51 \\
\hline Cultivar ( & & & & & & & \\
\hline \multicolumn{2}{|c|}{ Northeaster } & 26.53 & 16.14 & 32.37 & 49.17 & 28.33 & 32.05 \\
\hline \multicolumn{2}{|c|}{ Primetime } & 27.05 & 18.93 & 31.73 & 52.23 & 26.54 & 32.65 \\
\hline \multicolumn{2}{|c|}{ Analysis of variance } & \multicolumn{3}{|c|}{$P$ value } & \multicolumn{3}{|c|}{$P$ value } \\
\hline Source & df & L & Hue & $\overline{\text { Chroma }}$ & $\mathrm{L}$ & Hue & Chroma \\
\hline$\overline{\mathrm{GC}}$ & 2 & 0.1291 & 0.0015 & 0.0014 & 0.0185 & 0.0001 & 0.0002 \\
\hline $\mathrm{CV}$ & 1 & 0.2021 & 0.0001 & 0.0166 & 0.0001 & 0.0001 & 0.0133 \\
\hline $\mathrm{GC} \times \mathrm{CV}$ & 2 & 0.3761 & 0.2635 & 0.2186 & 0.2348 & 0.7852 & 0.0743 \\
\hline
\end{tabular}

${ }^{\mathrm{x}} \mathrm{L}=$ lightness to darkness; $100=$ pure white, $0=$ pure black

${ }^{\mathrm{y}} \mathrm{Hue}$ angle in degrees; $90=$ pure yellow, $0=$ pure red.

${ }^{\mathrm{x}} \mathrm{Chroma}$; higher values indicate greater pigment intensity. ethanol, then dried in a vacuum desiccator and used for the starch determinations. Derivatization of the sugars was performed according to the procedures described by Wang et al.(1987). Starch was hydrolyzed to glucose with amyloglucosidase (EC 3.2.1.3) (Sigma, St. Louis) in $100 \mathrm{~mm}$ of acetate buffer, $\mathrm{pH} 4.5$ (Zhang and Archbold, 1993), and analyzed for glucose using a peroxidase-glucose oxidase (PGO) procedure (Sigma, 1996).

Organic acid analysis. A Baker 10 extraction system (Phillipsburg, N.J.) was used for purification of the organic acids in strawberry leaves, petioles, crowns, crown-roots, roots, and fruit. Twenty grams of composited frozen fruit tissue or $5 \mathrm{~g}$ of each vegetative tissue were extracted with $100 \mathrm{~mL} 20 \mathrm{~mm}$ imidazole buffer (pH 7.0); then a 40-mL aliquot was placed onto 3-mL quaternary amine columns, which were previously conditioned with hexane and methanol. The organic acids were eluted with $6 \mathrm{~mL}$ of $0.1 \mathrm{~N} \mathrm{HCl}$. The eluate was concentrated to dryness under vacuum. Derivatization and determination of the organic acids via a gas chromatographic technique were conducted as previous described (Wang et al., 1987).

Ascorbic acid analysis. Ascorbic acid (AA) was extracted by grinding $25 \mathrm{~g}$ of partially thawed fruit with $100 \mathrm{~mL}$ of $1 \%$ oxalic acid in a homogenizer for $1 \mathrm{~min}$. The extract was filtered through no. 1 filter paper; then $1 \mathrm{~mL}$ of the filtered extract was mixed with $7 \mathrm{~mL}$ of $1 \%$ oxalic acid. Determination of AA was based on the reaction of 2,6 , dichloroindophenol dye and ascorbic acid, as described by Lundergan and Moore (1975).

Ellagic acid analysis. High-performance liquid chromatography (HPLC) was used to separate and determine ellagic acid content of tissue samples (Wang et al., 1994). Fruit samples (5.0 g each) and plant tissue samples $(1.0 \mathrm{~g}$ each) were extracted twice in $10 \mathrm{~mL}$ aqueous acetone (1:4). Extracts were combined $(20 \mathrm{~mL})$ and concentrated to $1 \mathrm{~mL}$ using a Buchler Evapomix (Fort Lee, N.J.), then hydrolyzed in $1 \mathrm{~mL}$ of $4 \mathrm{~N}$ trifluoroacetic acid (TFAA) at $100^{\circ} \mathrm{C}$ for $1 \mathrm{~h}$. The samples were passed through $0.45 \mu \mathrm{m}$ Millipore membrane 
filters (MSI, Westboro, Mass.) before HPLC injection. The samples were analyzed within 2 $\mathrm{h}$ after treatment using TFAA and a Waters (Waters Associates, Millipore Corp., Milford, Mass.) HPLC system equipped with two pumps (600 E system Controller). Samples were injected, using a Waters U6K injector, onto a reverse phase $8 \mathrm{~mm} \times 10 \mathrm{~cm} \mathrm{C}_{18}$ Radial-PAK Column containing $5-\mu \mathrm{m}$-sized particles (Water Associates) at room temperature; spectrophotometric detection was performed at 254 $\mathrm{nm}$. The mobile phase was a binary mixture of solvent A (methanol) and solvent B (redistilled water adjusted to $\mathrm{pH} 2.5$ with $0.6 \mathrm{M}$ perchloric acid). A linear gradient was carried out from $10 \%$ to $98 \%$ Solvent A for $15 \mathrm{~min}$ at a flow rate of $1.0 \mathrm{~mL} \cdot \mathrm{min}^{-1}$. The retention time of ellagic acid at this flow rate was $\approx 11.67 \mathrm{~min}$. An ellagic acid calibration curve was constructed every day. HPLC was run using four different ellagic acid $(0.5$ to $50 \mu \mathrm{g})$ standard concentrations (ellagic acid dihydrate, 97\% purity; Aldrich Chemical Co., Milwaukee).

Statistical analysis. The variables were analyzed as completely randomized two factor split-plot models using PROC MIXED (SAS Institute, 1996). Mulch (GC) was the whole-plot factor and cultivar (CV), the subplot factor. Variables were transformed when necessary to correct for variance heterogeneity, and the transformed values were analyzed. Least significant differences (LSDS) at the 0.05 significance level were calculated for the variables not transformed. For transformed variables, pair-wise contrasts of the transformed means were examined. All means are reported in the original measurement units.

\section{Results and Discussion}

Fruit surface and flesh color. Fruit surface brightness ( $\mathrm{L}^{*}$ value) was not affected by mulch treatment or genotype (Table 1). Surface color of the fruit grown on straw-vetch was less red (higher hue value), but had greater pigment intensity (higher chroma value) than that of fruit grown on black polyethylene or red polyethylene mulches. The flesh of the fruit grown on straw-vetch mulch had the darkest color (lowest $\mathrm{L}^{*}$ value), the least redness (highest hue value), and greatest pigment intensity (highest chroma value). Strawberries grown on black polyethylene had the reddest fruit flesh (lowest hue value) (Table 1).

'Northeaster' and 'Primetime' had similar fruit brightness, but the surface color of 'Northeaster' was redder and had greater pigment intensity than that of 'Primetime'. The flesh color of 'Northeaster' was darker than that of 'Primetime', but, contrary to the skin color (hue angle value) for the two genotypes, 'Primetime' flesh color was redder and also had greater pigment intensity than that of 'Northeaster' (Table 1).

Fruit SSC, TA, and AA. The fruit SSC and AA contents of 'Primetime' were higher than those of 'Northeaster' (Table 2), but TA content did not differ significantly. Strawberries grown on straw-vetch had significantly lower fruit SSC than did those grown on black polyethylene ('Northeaster') or red polyethylene
Table 2. Fruit soluble solids content (SSC), titratable acids (TA), ascorbic acid (AA), leaf chlorophyll content (SPAD-502 units), and leaf area (LA) of 'Northeaster' and 'Primetime' strawberries grown in different mulch types.

\begin{tabular}{|c|c|c|c|c|c|}
\hline Treatment (GC) & $\begin{array}{l}\text { SSC } \\
(\%)\end{array}$ & $\begin{array}{l}\text { TA } \\
(\%)\end{array}$ & $\begin{array}{c}\mathrm{AA} \\
(\mathrm{mg} \cdot 100 \mathrm{~g} \text { fresh mass })\end{array}$ & $\begin{array}{l}\text { Chlorophyll } \\
\text { (unit) }\end{array}$ & $\begin{array}{c}\text { LA } \\
\left(\mathrm{cm}^{2} / \text { leaf }\right)\end{array}$ \\
\hline & & & Northeaster & & \\
\hline Black polyethylene & 8.80 & 0.814 & 49.34 & $28.86^{2}$ & 49.28 \\
\hline Red polyethylene & 8.68 & 0.904 & 49.14 & 26.52 & 47.00 \\
\hline \multirow[t]{2}{*}{ Straw-vetch } & 8.52 & 0.872 & 50.60 & 29.48 & 55.54 \\
\hline & & & Primetime & & \\
\hline Black polyethylene & 8.30 & 0.862 & 76.88 & 30.32 & 48.18 \\
\hline Red polyethylene & 8.38 & 0.852 & 77.90 & 27.04 & 44.76 \\
\hline Straw-vetch & 8.16 & 0.910 & 75.26 & 32.30 & 64.02 \\
\hline LSD $_{0.05}$ (within) ${ }^{y}$ & 0.21 & 0.020 & 1.40 & 0.66 & 0.78 \\
\hline $\operatorname{LSD}_{0.05}(\text { between })^{\mathrm{x}}$ & 0.24 & 0.021 & 1.46 & 0.87 & 0.80 \\
\hline Analysis of variance & & & $P$ value & & \\
\hline Source & SSC & TA & AA & Chlorophyll & LA \\
\hline$\overline{\mathrm{GC}}$ & 0.0125 & 0.0001 & 0.4760 & 0.0001 & 0.0001 \\
\hline Cultivar (CV) & 0.0001 & 0.0699 & 0.0001 & 0.0001 & 0.0001 \\
\hline $\mathrm{GC} \times \mathrm{CV}$ & 0.4464 & 0.0001 & 0.0030 & 0.0055 & 0.0001 \\
\hline
\end{tabular}

${ }^{\mathrm{z}}$ Higher units indicate higher chlorophyll content.

${ }^{y}$ Comparing treatments within a cultivar.

${ }^{\mathrm{x}}$ Comparing treatments between cultivars.

Table 3. Fruit sugar content of 'Northeaster' and 'Primetime' strawberries grown in different mulch types.

\begin{tabular}{|c|c|c|c|}
\hline Treatment (GC) & Fructose & Glucose & Sucrose \\
\hline & & Northeaster & \\
\hline Black polyethylene & 21.52 & 20.22 & 11.82 \\
\hline Red polyethylene & 21.30 & 20.54 & 11.96 \\
\hline \multirow{2}{*}{ Straw-vetch } & 20.16 & 21.40 & 12.28 \\
\hline & & Primetime & \\
\hline Black polyethylene & 19.30 & 20.20 & 17.62 \\
\hline Red polyethylene & 20.28 & 19.98 & 17.10 \\
\hline Straw-vetch & 19.50 & 18.94 & 16.06 \\
\hline LSD $_{0.05}$ (within) ${ }^{z}$ & 0.79 & 0.75 & 0.49 \\
\hline $\mathrm{LSD}_{0.05}(\text { between })^{\mathrm{y}}$ & 0.71 & 0.89 & 0.55 \\
\hline Analysis of variance & \multicolumn{3}{|c|}{$P$ value } \\
\hline Source & Fructose & Glucose & Sucrose \\
\hline$\overline{\mathrm{GC}}$ & 0.0264 & 0.9189 & 0.0132 \\
\hline CV (cultivar) & 0.0001 & 0.0011 & 0.0001 \\
\hline $\mathrm{GC} \times \mathrm{CV}$ & 0.0132 & 0.0031 & 0.0003 \\
\hline
\end{tabular}

${ }^{\mathrm{r}}$ Comparing treatments within a cultivar.

${ }^{y}$ Comparing treatments between cultivars.

Table 4. Fruit organic acid and ellagic acid content of 'Northeaster' and 'Primetime' strawberries grown in different mulch types.

\begin{tabular}{|c|c|c|c|c|}
\hline \multirow[b]{2}{*}{ Treatment (GC) } & Malic acid & Citric acid & Quinic acid & \multirow{2}{*}{$\frac{\text { Ellagic acid }}{\mu \mathrm{g} \cdot \mathrm{g}^{-1} \text { fresh mass }}$} \\
\hline & \multicolumn{3}{|c|}{$\mathrm{mg} \cdot \mathrm{g}^{-1}$ fresh mass } & \\
\hline & \multicolumn{4}{|c|}{ Northeaster } \\
\hline Black polyethylene & 0.58 & 3.46 & 0.20 & $144.33 \mathrm{a}^{*_{z}}$ \\
\hline \multirow{3}{*}{ Straw-vetch } & 0.65 & 3.30 & 0.21 & $128.19 \mathrm{~b}^{*}$ \\
\hline & 0.62 & 4.34 & 0.24 & $137.76 \mathrm{c}^{*}$ \\
\hline & \multicolumn{4}{|c|}{ Primetime $^{0.24}$} \\
\hline Black polyethylene & 0.80 & 4.88 & 0.18 & $241.65 \mathrm{~b}$ \\
\hline Red polyethylene & 0.86 & 4.34 & 0.15 & $258.31 \mathrm{a}$ \\
\hline Straw-vetch & 0.82 & 4.60 & 0.19 & $251.99 \mathrm{a}$ \\
\hline LSD $_{0.05}$ (within $)^{y}$ & 0.03 & 0.10 & 0.023 & --- \\
\hline LSD $_{0.05}(\text { between })^{\mathrm{x}}$ & 0.03 & 0.10 & 0.023 & -- \\
\hline Analysis of variance & \multicolumn{4}{|c|}{$P$ value } \\
\hline Source & Malic acid & Citric acid & Quinic acid & Ellagic acid \\
\hline $\overrightarrow{\mathrm{GC}}$ & 0.0002 & 0.0001 & 0.0001 & 0.0005 \\
\hline Cultivar (CV) & 0.0001 & 0.0001 & 0.0001 & 0.0001 \\
\hline $\mathrm{GC} \times \mathrm{CV}$ & 0.6648 & 0.0001 & 0.0519 & 0.0001 \\
\hline
\end{tabular}

${ }^{7}$ Analysis on transformed values, LSDs are not appropriate. Letters are comparisons of treatments within a cultivar and asterisks are comparisons of treatments between cultivars.

${ }^{y}$ Comparing treatments within a cultivar.

${ }^{\times}$Comparing treatments between cultivars. 
('Primetime'). However, there was no difference in SSC between fruits grown on black polyethylene and those grown on red polyethylene in either cultivar. 'Northeaster' fruit grown on red polyethylene contained higher TA than those grown on the other two types of mulch, but 'Primetime' fruit grown on strawvetch had higher TA than fruit grown on the other mulches. The mulch $\times$ cultivar interaction was significant for fruit TA and AA, but not for SSC (Table 2).

Fruit sugar, organic acid, and ellagic acid content. Fruit sugar content was more influenced by cultivar and cultivar $\times$ mulch interaction than by mulch type (Table 3 ). 'Northeaster' fruit had higher fructose levels than did 'Primetime' fruits in the polyethylene mulch treatments. Fruit glucose levels were significantly higher in 'Northeaster' than in 'Primetime' for straw-vetch. Sucrose content was much lower in 'Northeaster' than in 'Primetime'. In 'Northeaster' the sucrose content did not differ significantly among mulch treatments. In 'Primetime' the sucrose content differed significantly among all three mulch treatments, with black polyethylene being the highest and straw-vetch the lowest.

Citric acid was the most abundant of the organic acids in the fruits sampled (Table 4). 'Primetime' fruit had significantly higher malic and citric acid contents than 'Northeaster', but 'Northeaster' had significantly higher quinic acid levels. Malic acid content was higher in both 'Northeaster' and 'Primetime' fruit grown on red polyethylene than in fruit grown on black polyethylene or straw-vetch. 'Northeaster' fruit grown on straw-vetch and 'Primetime' fruit grown on black polyethylene had the highest contents of citric acid. Fruit grown on straw-vetch had the highest quinic acid. However, for 'Primetime' the values for straw vetch were not significantly different from those for black polyethylene (Table 4). 'Primetime' fruit had significantly more ellagic acid than did 'Northeaster' fruit (Table 4). Ellagic acid levels were highest in 'Northeaster' fruit grown on black polyethylene and in 'Primetime' fruit grown on red polyethylene and straw-vetch.

Leaf chlorophyll content and leaf area. Mulch, cultivar and mulch $\times$ cultivar interaction effects on chlorophyll content and leaf area were highly significant (Table 2). The chlorophyll contents of 'Primetime' were higher than those of 'Northeaster'. For both genotypes, leaves contained the highest chlorophyll content on straw-vetch mulch, and the least on red polyethylene mulch. 'Northeaster' had larger leaves than 'Primetime' when grown on either polyethylene mulch, but not when grown on the straw-vetch mulch. Leaves grown on straw-vetch mulch were significantly larger than those grown on the other two mulches, with the red polyethylene mulch producing the smallest leaves.

Carbohydrate and starch contents in plant tissues. Mulch types and cultivars greatly affected the carbohydrate and starch content of tissues (Tables 5 and 6). In general, the red polyethylene treatment yielded the lowest levels of soluble carbohydrates and starch, whereas

Table 5. Soluble carbohydrates and starch (mg. $\mathrm{g}^{-1}$ dry mass) in leaves, petioles, crowns, crown-roots, and roots of 'Northeaster' and 'Primetime' strawberries grown in different mulch types.

\begin{tabular}{|c|c|c|c|c|c|c|}
\hline \multirow[b]{2}{*}{ Treatment (GC) } & \multicolumn{6}{|c|}{ Carbohydrate } \\
\hline & Fructose & Glucose & Myoinositol & Sucrose & Starch & Total \\
\hline \multicolumn{7}{|c|}{ Leaves, Northeaster } \\
\hline Black polyethylene & 25.00 & 30.36 & 11.72 & 28.92 & $8.03 \mathrm{~b}^{*_{2}}$ & $104.03 \mathrm{a}^{*}$ \\
\hline Red polyethylene & 17.20 & 20.68 & 5.56 & 21.04 & $8.14 b^{*}$ & $72.82 c^{*}$ \\
\hline Straw-vetch & 23.28 & 26.28 & 9.12 & 30.00 & $9.26 \mathrm{a}^{*}$ & $96.09 b^{*}$ \\
\hline \multicolumn{7}{|c|}{ Leaves, Primetime } \\
\hline Black polyethylene & 19.44 & 33.28 & 12.92 & 49.64 & $23.18 \mathrm{a}$ & $138.37 \mathrm{a}$ \\
\hline Red polyethylene & 17.84 & 19.24 & 12.92 & 47.92 & $23.17 \mathrm{a}$ & $121.09 \mathrm{~b}$ \\
\hline Straw-vetch & 17.40 & 25.88 & 14.08 & 47.54 & $18.10 \mathrm{~b}$ & $123.00 \mathrm{~b}$ \\
\hline $\operatorname{LSD}_{0.05}(\text { within })^{\mathrm{y}}$ & 0.96 & 0.93 & 0.82 & 0.87 & --- & --- \\
\hline LSD $_{0.05}(\text { between })^{x}$ & 1.11 & 0.76 & 1.04 & 0.97 & --- & --- \\
\hline \multicolumn{7}{|c|}{ Petioles, Northeaster } \\
\hline Black polyethylene & $50.50 \mathrm{a}^{*}$ & 136.50 & 4.16 & $8.86 \mathrm{~b}^{*}$ & 10.04 & 210.00 \\
\hline Red polyethylene & $39.23 c^{*}$ & 119.54 & 2.46 & $8.46 \mathrm{c}^{*}$ & 10.04 & 179.72 \\
\hline Straw-vetch & $46.70 b^{*}$ & 118.92 & 3.38 & $14.61 \mathrm{a}^{*}$ & 14.52 & 198.14 \\
\hline \multicolumn{7}{|c|}{ Petioles, Primetime } \\
\hline Black polyethylene & $33.85 \mathrm{a}$ & 132.54 & 5.38 & $38.92 \mathrm{a}$ & 32.80 & 243.50 \\
\hline Red polyethylene & $29.69 \mathrm{~b}$ & 112.46 & 4.40 & $31.53 \mathrm{~b}$ & 20.26 & 198.36 \\
\hline Straw-vetch & $30.54 \mathrm{~b}$ & 118.46 & 5.68 & $31.31 \mathrm{~b}$ & 25.62 & 211.62 \\
\hline LSD $_{0.05}$ (within) ${ }^{\mathrm{z}}$ & --- & 2.60 & 0.40 & --- & 1.24 & 3.11 \\
\hline $\mathrm{LSD}_{0.05}(\text { between })^{\mathrm{y}}$ & --- & 2.76 & 0.50 & --- & 1.35 & 2.63 \\
\hline \multicolumn{7}{|c|}{ Crowns, Northeaster } \\
\hline Black polyethylene & 33.46 & $55.39 \mathrm{~b}^{*}$ & 4.98 & 60.46 & 32.28 & 186.60 \\
\hline Red polyethylene & 20.50 & $38.69 \mathrm{c}^{*}$ & 5.10 & 30.06 & 35.44 & 129.80 \\
\hline Straw-vetch & 30.94 & $57.49 \mathrm{a}^{*}$ & 6.10 & 35.70 & 37.70 & 166.70 \\
\hline \multicolumn{7}{|c|}{ Crowns, Primetime } \\
\hline Black polyethylene & 40.88 & 73.89 a & 9.38 & 52.62 & 91.88 & 268.74 \\
\hline Red polyethylene & 38.98 & $64.05 \mathrm{c}$ & 9.12 & 42.28 & 74.30 & 228.72 \\
\hline Straw-vetch & 40.52 & $69.41 \mathrm{~b}$ & 8.90 & 46.18 & 73.96 & 238.98 \\
\hline LSD $_{0.05}$ (within) ${ }^{y}$ & 1.03 & --- & 0.45 & 1.90 & 2.11 & 3.41 \\
\hline $\mathrm{LSD}_{0.05}(\text { between })^{\mathrm{x}}$ & 1.18 & --- & 0.46 & 2.19 & 2.19 & 3.50 \\
\hline \multicolumn{7}{|c|}{ Crown-roots, Northeaster } \\
\hline Black polyethylene & 25.48 & 35.34 & 3.44 & $8.60 \mathrm{c}^{*}$ & 94.40 & $167.29 \mathrm{~b}^{*}$ \\
\hline Red polyethylene & 22.26 & 24.78 & 2.22 & $13.15 \mathrm{a}^{*}$ & 94.32 & $156.73 c^{*}$ \\
\hline Straw-vetch & 30.38 & 37.60 & 3.14 & $12.15 b^{*}$ & 95.98 & $179.85 \mathrm{a}^{*}$ \\
\hline \multicolumn{7}{|c|}{ Crown-roots, Primetime } \\
\hline Black polyethylene & 34.08 & 68.50 & 6.16 & $48.44 \mathrm{a}$ & 96.70 & $253.88 \mathrm{a}$ \\
\hline Red polyethylene & 34.44 & 61.30 & 5.04 & $37.85 \mathrm{~b}$ & 93.96 & $232.56 \mathrm{~b}$ \\
\hline Straw-vetch & 36.10 & 62.42 & 5.80 & $37.22 \mathrm{c}$ & 93.28 & $234.83 \mathrm{~b}$ \\
\hline $\mathrm{LSD}_{0.05}$ (within) & 1.21 & 0.93 & 0.35 & --- & 1.55 & --- \\
\hline $\mathrm{LSD}_{0.05}$ (between) & 1.37 & 0.98 & 0.20 & --- & 1.71 & --- \\
\hline \multicolumn{7}{|c|}{ Roots, Northeaster } \\
\hline Black polyethylene & 4.60 & 8.24 & 0.64 & $0.37 \mathrm{~b}^{*}$ & 25.38 & 46.10 \\
\hline Red polyethylene & 2.72 & 4.70 & 0.60 & $0.55 \mathrm{a}^{*}$ & 24.86 & 36.22 \\
\hline Straw-vetch & 3.82 & 3.94 & 0.54 & $0.38 \mathrm{~b}^{*}$ & 25.16 & 40.26 \\
\hline \multicolumn{7}{|c|}{ Roots, Primetime } \\
\hline Black polyethylene & 5.58 & 8.16 & 0.88 & $0.27 \mathrm{a}$ & 22.22 & 50.50 \\
\hline Red polyethylene & 2.86 & 6.74 & 0.68 & $0.27 \mathrm{a}$ & 25.00 & 48.60 \\
\hline Straw-vetch & 5.56 & 8.02 & 0.88 & $0.27 \mathrm{a}$ & 24.28 & 52.34 \\
\hline $\mathrm{LSD}_{0.05}$ (within) & 0.32 & 0.32 & 0.14 & --- & 0.70 & 1.10 \\
\hline $\mathrm{LSD}_{0.05}$ (between) & 0.30 & 0.36 & 0.09 & --- & 0.68 & 1.05 \\
\hline
\end{tabular}

${ }^{2}$ Analysis on transformed values so LSDS are not appropriate. Letters are comparisons of treatments within a cultivar and asterisks are the comparisons of the same treatments between cultivars.

${ }^{y}$ Comparing the treatments within a cultivar.

${ }^{\mathrm{x}}$ Comparing the same treatment between cultivars.

the black polyethylene treatment produced the highest levels in both cultivars. Fructose and glucose levels were highest in leaf, petiole, and root tissues for both cultivars when grown on black polyethylene.

Specifically, in 'Primetime', growth on black polyethylene produced significantly higher levels of sucrose and total carbohydrates in leaves, petioles, crowns, and crown roots. 'Primetime' grown on black polyethylene also contained significantly higher levels of starch in petioles, crowns, and crown roots. 'Primetime' grown on red polyethylene con- tained the highest root starch levels. There appeared to be no significant difference between black polyethylene and red polyethylene treatments in the starch levels of 'Primetime' leaves.

When grown on black polyethylene, 'Northeaster' leaf and petiole tissues contained high amounts of fructose, glucose, and myoinositol. Crown tissues had the highest fructose and sucrose content, and root tissues contained the highest content of total carbohydrates. However, the highest levels of myoinositol and starch in crown tissues, and soluble 
Table 6. Analysis of variance for soluble carbohydrates and starch from Table 5.

\begin{tabular}{|c|c|c|c|c|c|c|c|}
\hline \multirow[b]{2}{*}{ Source } & \multirow[b]{2}{*}{ df } & \multicolumn{6}{|c|}{$P$ value } \\
\hline & & Fructose & Glucose & Myoinositol & Sucrose & Starch & Total \\
\hline \multicolumn{8}{|c|}{ Leaves } \\
\hline Treatment (GC) & 2 & 0.0001 & 0.0001 & 0.0001 & 0.0001 & 0.0119 & 0.0001 \\
\hline Cultivar (CV) & 1 & 0.0001 & 0.0991 & 0.0001 & 0.0001 & 0.0010 & 0.0001 \\
\hline $\mathrm{GC} \times \mathrm{CV}$ & 2 & 0.0001 & 0.0001 & 0.0001 & 0.0001 & 0.0001 & 0.0001 \\
\hline \multicolumn{8}{|c|}{ Petioles } \\
\hline GC & 2 & 0.0001 & 0.0001 & 0.0001 & 0.0001 & 0.0001 & 0.0001 \\
\hline $\mathrm{CV}$ & 1 & 0.0001 & 0.0002 & 0.0001 & 0.0001 & 0.0001 & 0.0001 \\
\hline $\mathrm{GC} \times \mathrm{CV}$ & 2 & 0.0001 & 0.0105 & 0.0171 & 0.0001 & 0.0001 & 0.0001 \\
\hline \multicolumn{8}{|c|}{ Crowns } \\
\hline $\mathrm{GC}$ & 2 & 0.0001 & 0.0001 & 0.0642 & 0.0001 & 0.0001 & 0.0001 \\
\hline $\mathrm{CV}$ & 1 & 0.0001 & 0.0001 & 0.0001 & 0.0001 & 0.0001 & 0.0001 \\
\hline $\mathrm{GC} \times \mathrm{CV}$ & 2 & 0.0001 & 0.0001 & 0.0004 & 0.0001 & 0.0001 & 0.0001 \\
\hline \multicolumn{8}{|c|}{ Crown-roots } \\
\hline GC & 2 & 0.0001 & 0.0001 & 0.0001 & 0.0001 & 0.0469 & 0.0001 \\
\hline $\mathrm{CV}$ & 1 & 0.0001 & 0.0001 & 0.0001 & 0.0001 & 0.5855 & 0.0001 \\
\hline $\mathrm{GC} \times \mathrm{CV}$ & 2 & 0.0001 & 0.0001 & 0.4966 & 0.0001 & 0.0026 & 0.0001 \\
\hline \multicolumn{8}{|c|}{ Roots } \\
\hline GC & 2 & 0.0001 & 0.0001 & 0.1706 & 0.0001 & 0.0021 & 0.0001 \\
\hline $\mathrm{CV}$ & 1 & 0.0001 & 0.0001 & 0.0001 & 0.0001 & 0.0001 & 0.0001 \\
\hline $\mathrm{GC} \times \mathrm{CV}$ & 2 & 0.0010 & 0.0001 & 0.0038 & 0.0001 & 0.0001 & 0.0001 \\
\hline
\end{tabular}

carbohydrates and starch in crown roots were observed on straw-vetch.

In summary, mulch type and cultivar appear to affect the fruit quality parameters and plant carbohydrate pool. In general, plant tissues from 'Primetime' had a higher content of carbohydrates than those of 'Northeaster', and the black polyethylene treatment tended to produce the highest levels of soluble carbohydrates and starch in both cultivars.

There is a close relationship between photosynthesis and absorption of energy by chlorophyll (Noggle and Fritz, 1983). The low carbohydrate content in plants grown on red polyethylene may reflect a low chlorophyll content and leaf area. Increases in yield, fruit size, and sweetness observed in other trials with red mulch (Galletta et al., 1996) were not confirmed in this study (data not shown), probably due to the different genotypes and the short duration of the red plastic mulch treatment (from spring leaf emergence to fruit harvest).

Different mulches probably led to differences in canopy temperature, soil temperature and moisture content, and the quantity and quality of light transmitted, reflected, or absorbed. These differences in turn may have affected plant growth, development, fruit quality, and carbohydrate metabolism in strawberry plants.
Himelrick, D.G. 1982. Effect of polyethylene mulch color on soil temperatures and strawberry plant response. Adv. Strawberry Prod. 1:15-16.

Locascio, S.J. and G.C. Smart, Jr. 1968. Influence of polyethylene mulch colors and soil fumigants on strawberry production. Proc. Fla. State. Hort. Soc. 81:147-153.

Lundergan, C.A. and J.N. Moore. 1975. Inheritance of ascorbic acid content and color intensity in fruits of strawberry (Fragaria $\times$ ananassa Duch.). J. Amer. Soc. Hort. Sci. 100:633-635.

Maas, J.L., G.J. Galletta, and G.D. Stoner. 1991a. Ellagic acid, an anticarcinogen in fruits, especially in strawberries: A review. HortScience 26:10-14.

Maas, J.L., G.J. Galletta, and S.Y. Wang. 1992. Ellagic acid enhancement in strawberries, $\mathrm{p}$. 345-362. In: D.D. Bills and S.D. Kung (eds.). Biotechnology and nutrition; proceedings of the third symposium. Butterworth-Heineman. Intl. Symp. Biotechnol. Nutr., College Park, Md.

Maas, J.L., S.Y. Wang, and G.J. Galletta. 1991b. Evaluation of strawberry cultivars for ellagic acid content. HortScience 26:66-68.

Marquard, R.D. and J.L. Tipton. 1987. Relationship between extractable chlorophyll and an in situ method to estimate leaf greenness. HortScience 22:1327.

Noggle, G.R. and G.J. Fritz. 1983. Introductory plant physiology. 2nd ed. Prentice Hall, Englewood Cliffs, N.J.

Abdul-Baki, A.A. and J.R. Teasdale. 1993. A notillage tomato production system using hairy vetch and subterranean clover mulches. HortScience 28:106-108.

Albregts, E.E. and C.K. Chandler. 1993. Effect of polyethylene mulch color on fruiting response of strawberry. Proc. Soil Crop Sci. Florida. $52: 40-43$.

Baumann, T.E. and G.W. Eaton. 1991. Season extension of day-neutral and ever-bearing strawberries in the hill row system. Adv. Strawberry Prod. 10:49-52.

Baumann, T.E., G.W. Eaton, A. Machholz, and D. Spaner. 1995. Day-neutral strawberry production on raised beds in British Columbia. Adv. Strawberry Res. 14:53-57.

Cannell, G.H., V. Voth, R.S. Bringhurst, and E.L Proebsting. 1961. The influence of irrigation levels and application methods, polyethylene mulch and nitrogen fertilization on strawberry production in Southern California. Proc. Amer. Soc. Hort. Sci. 28:281-291.

Decoteau, D.R., M.J. Kasperbauer, and P.G. Hunt. 1989. Mulch surface color affects yield of freshmarket tomato. J. Amer. Soc. Hort. Sci. 114:216219.

Francis, F.J. 1980. Color quality evaluation of horticultural crops. HortScience 15:58-59.

Galletta, G.J., J.M. Enns, and J.L. Maas. 1996 Strawberry cultivar responses to variations in planting time, stock, and mulches. HortScience 31:610.
Okuda, T., T. Yoshida, and T. Hatano. 1989. Ellagitannins as active constituents of medical plants. Planta Med. 55:117-122.

Sacks, E.J. and D.V. Shaw. 1994. Optimum allocation of objective color measurements for evaluating fresh strawberries. J. Amer. Soc. Hort. Sci. 119:330-334.

SAS Institute. 1996. SAS/STAT software: Changes and enhancements through release 6.11. SAS Inst., Cary, N.C.

Scheel, D.C. 1982. The effect of clear polyethylene winter mulch on the growth and yield of strawberries. Adv. Strawberry Prod. 1:29-30.

Sigma Diagnostics, Inc. 1996. Glucose. Sigma Technical Bul. 510A. St. Louis. for strawberries. 1. Effect of a killed sod mulch on raised bed erosion and soil compaction in the first season. Adv. Strawberry Prod. 7:16-18.

Wang, S.Y., Z.L. Ji, and M. Faust. 1987. Metabolic changes associated with bud break induced by thidiazuron. J. Plant Growth Regulat. 6:85-95.

Wang, S.Y., J.L. Maas, J.A.Payne, and G.J. Galletta. 1994. Ellagic acid content in small fruits, mayhaws, and other plants. J. Small Fruit and Viticulture 2:39-49.

Zhang, B. and D.D. Archbold. 1993. Solute accumulation in leaves of a Fragaria chiloensis and a $F$. virginiana selection responds to water deficit stress. J. Amer. Soc. Hort. Sci. 118:280-285.
Takeda, F. and D.M. Glenn. 1988. Soil management 